\title{
Tinjauan Pelaksanaan Pemeliharaan Dokumen Rekam Medis Di Ruangan Filling Rumah Sakit DR. Pirngadi Medan Tahun 2019
}

\author{
${ }^{1}$ Esraida Simanjuntak, ${ }^{2}$ Rizka Mei Shella \\ Program Studi D-III Perekam dan Informasi Kesehatan, Universitas Imelda Medan
}

\section{Article Info}

Article history:

Received July 13,2020

Revised August 14, 2020

Accepted August 29, 2020

\section{Keywords:}

Maintenance of medical record

Documents

Filling space

\begin{abstract}
Maintenance of medical record documents is a combination of various activities undertaken to maintain documents and production facilities including other production equipment or to repair them to a condition that is well accepted. Physical danger is damage to documents caused by sunlight, rain, flood, heat and humidity. Chemical hazard is document damage caused by food, beverages, and chemicals. Biological hazard is document damage caused by rats, cockroaches, and termites. The purpose of this study is to describe the implementation of maintenance of medical record documents in the room Dr. hospital filling Pirngadi Medan in 2019. This type of research is a description of the interview and observation methods. The place of research was conducted at Dr. Pirngadi Medan due to the inability of maintaining medical record documents. When the study was conducted in March-April 2019. Population and samples used were all medical record storage officers, amounting to 3 people. Based on the results of the study, there were still racks that used wood and did not use rool o'pack cabinets, there are damaged medical record documents that have not been replaced with new ones due to lack of cover inventory. The temperature and humidity of the room in the storage room are less controlled. The conclusion of this study is that the maintenance of medical record documents has not been carried out because the shelves are still made from wood and the lack of storage rack facilities make medical records documents partially placed under the floor. The suggestion from this research is that it is better to use a rool o'pack cupboard and keep the air conditioner on for 24 hours according to the theory.
\end{abstract}

This is an open access article under the CC BY-SAlicense.

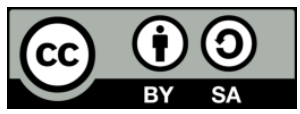

\section{Corresponding Author:}

Esraida Simanjuntak,

Program Studi D-3 Perekam dan Informasi Kesehatan,

Universitas Imelda Medan,

Jl. Bilal No. 52 Kelurahan Pulo Brayan Darat I Kecamatan Medan Timur, Medan - Sumatera Utara.

Email: esraida.borjun@gmail.com

\section{PENDAHULUAN}

Rekam medis menurut Permenkes No. 269 tahun 2008 adalah berkas yang berisikan catatan dan dokumen tentang identitas pasien, pemeriksaan, pengobatan, tindakan, pelayanan lain yang telah diberikan kepada pasien. Rekam medis merupakan bukti tertulis 
tentang proses pelayanan yang diberikan oleh dokter dan tenaga medis kesehatan lainnya kepada pasien.

Menurut Permenkes No.55 tahun 2013 tentang penyelenggaraan pekerjaan perekam medis pasal 1 yaitu manajemen pelayanan rekam medis dan informasi kesehatan adalah kegiatan menjaga, memelihara dan melayani rekam medis baik secara manual maupun elektronik sampai menyajikan informasi kesehatan di rumah sakit, praktik dokter klinik, asuransi kesehatan, fasilitas pelayanan kesehatan dan lainnya yang menyelenggarakan pelayanan kesehatan dan menjaga rekaman.

Fungsi dokumen rekam medis bagi rumah sakit adalah sebagai sumber ingatan dan sebagai sumber informasi dalam rangka melaksanakan perencanaan, penganalisaan, pengambilan keputusan, penilaian, dan dipertanggungjawabkan dengan sebaik-baiknya untuk mendukung terciptanya keberhasilan penyimpanan, pengamanan, dan pemeliharaan dokumen rekam medis diperlukan adanya ketentuan pokok kearsipan yaitu tempat, sarana prasarana, pemeliharaan dokumen dari bahaya dan kerusakan. Sistem pengelolaan rekam medis terdiri dari beberapa subsistem yaitu, dimulai dari tempat penerimaan pasien, assembling, coding, indexing dan filling. Di bagian filling dan pengembalian kembali rekam medis dilakukan, penyimpanan berkas rekam medis yang disimpan dalam rak filling, mudah mengambil dari tempat penyimpanan, mudah pengambilannya, melindungi berkas rekam dari bahaya kerusakan fisik, kimiawi dan biologis (Budi, 2011).

Bahaya fisik adalah kerusakan dokumen yang disebabkan oleh sinar matahari, hujan, banjir, panas dan kelembaban. Bahaya kimiawi adalah kerusakan dokumen yang disebabkan oleh makanan, minuman, dan bahan-bahan kimia. Bahaya biologis adalah kerusakan dokumen yang disebabkan oleh tikus, kecoa, dan rayap (Rustiyanto \& Rahayu, 2011).

Adapun dampak yang disebabkan oleh aspek tersebut adalah, dari segi fisik yaitu dokumen rekam medis dapat rusak, sehingga apabila terjadi perkara hukum dokumen rekam medis tidak akurat untuk dijadikan sebagai alat bukti. Dari segi kimiawi yaitu dapat membuat isi dokumen rekam medis pudar dan tidak bisa terbaca. Dari segi biologi yaitu dapat membuat isi dokumen rekam medis mengalami kerusakan pada beberapa formulir karena termakan rayap maupun jenis serangga lainnya.

Upaya pelaksanaan pemeliharaan dokumen rekam medis dapat dilakukan sebagaimana dilihat dari berbagai aspek, yaitu aspek fisik dengan cara mengganti folder yang telah rusak dengan yang baru, dari aspek kimia dengan cara menggunakan tinta yang berkualitas, dan dari aspek biologi dengan cara mengatur temperatur udara dengan baik dan menjaga kebersihan ruangan. Adapun upaya lain yang harus dilakukan dalam pemeliharaan dokumen rekam medis yaitu, setiap peminjaman harus melalui petugas filling dan dicatat dalam buku ekspedisi.

Hasil penelitian yang dilakukan di Rumah Sakit RA Kartini Jepara tahun 2015, terdapat 8 dokumen rekam medis yang rusak seperti cover dokumen rekam medis dan lembar formulir robek sehingga identitas dan nomor rekam medis pasien tidak terbaca. Pelaksanaan pemeliharaan dokumen rekam medis sebagian besar belum sesuai dengan teori yaitu terdapat beberapa folder yang rusak dan tidak diganti dengan yang baru dan menggunakan map folder yang lebih tebal agar dokumen rekam medis tidak mudah rusak. Selain itu kapasitas rak tidak sebanding dengan jumlah dokumen rekam medis, sarana pemeliharaan yang belum sesuai dengan teori karena terdapat beberapa rak yang terbuat dari kayu sehingga mudah diserang rayap. Adapun temperatur suhu di ruangan filling RSU RA Kartini Jepara belum memadai sehingga banyaknya debu dan menyebabkan kelembaban dan kerusakan dokumen rekam medis (Sari, 2015).

Hasil penelitian yang berjudul Tinjauan Aspek Keamanan Dan Kerahasiaan Dokumen Rekam Medis Di Ruang Filling Rumah Sakit Khusus (RSK) Paru Medan Tahun 2018 menyatakan hasil penelitian menunjukan dari segi aspek fisik tinta yang digunakan warna 
hitam sudah seragam.Kertas yang digunakan ukuran A4 berat 70 gram.Tidak adanya AC, APAR, tracer dan kamfer.Masih ada selain petugas rekam medis yang keluar masuk ke ruang filling sehingga dokumen rekam medis hilang.Pasien membawa sendiri dokumen rekam medisnya.Aspek biologis adanya jamur, kutu buku, dan serangga seperti rayap, kecoa, dan tikus.Aspek kimiawi adanya petugas rekam medis makan/minum di ruang rekam medis.Aspek kerahasiaanya masih ada petugas rekam medis yang masuk ke filling rekam medik dan masih ditemukan dokumen rekam medis yang di bawa pasien/hilang (Hutauruk \& Astuti, 2018).

Hasil penelitian (Ni Putu Tika Pramesti, 2014) tentang pemeliharaan rekam medis inaktif pasien jiwa di RSJ Grhasia DIY untuk pemeliharaan dokumen rekam medis inaktif masih ditemukan beberapa kendala antara lain belum maksimalnya pemeliharaan rekam medis karena belum ada standar operasional prosedur yang mengatur tentang pemeliharaan rekam medis, maka pelaksanaan pemeliharaan yang dilakukan masih dengan cara yang sederhana, belum memiliki job description pemeliharaan dokumen rekam medis, kurangnya ruang dan rak penyimpanan rekam medis inaktif, belum memiliki penanggungjawab, suhu ruangan tidak penah dipantau dan tidak memiliki alat pemadam api ringan.

Sedangkan penelitian lain yang berkaitan dengan Pemeliharaan Dokumen Rekam Medis Di Ruang Filing menyatakan bahwa pelaksanaan pemeliharaan dokumen rekam medis dapat dilihat dari aspek fisik bila terdapat folder yang telah rusak belum diganti dengan yang baru, menjaga kerahasiaan isi dokumen rekam medis belum sepenuhnya menjaga kerahasiaan isi dokumen rekam medis karena ruang filing tidak pernah terkunci, petugas filing dalam melayani peminjaman dokumen rekam medis tidak menggunakan tracer sebagai petunjuk keluar dari rak penyimpanan dan hanya menggunakan buku ekspedisi (Sandika \& Ernianita, 2019).

Berdasarkan survei awal di Rumah Sakit Dr. Pirngadi Medan bagian unit filling, ditemukan beberapa rak yang masih menggunakan bahan kayu dan belum menggunakan roll o'pack sehingga akan mengakibatkan mudah di serang rayap, sampul untuk dokumen rekam medis masih kurang dan masih banyak dokumen rekam medis yang diletakkan di lantai dalam keadaan tidak bersampul, AC yang terdapat di ruang filling tidak dinyalakan 24 jam sehingga membuat ruangan filling lembab dan berdebu. Hal ini yang menjadikan penulis tertarik untuk melakukan penelitian tentang "Tinjauan Pelaksanaan Pemeliharaan Dokumen Rekam Medis Di Ruangan Filling Rumah Sakit Dr. Pirngadi Medan Tahun 2019”.

\section{METODE PENELITIAN}

A. Jenis Penelitian

Jenis penelitian ini menggunakan penelitian deskriptif adalah penelitian yang tujuannya untuk menjelaskan atau mendeskripsikan suatu peristiwa, keadaan, objek apakah orang, atau segala sesuatu yang terkait dengan variabel-variabel yang bisa dijelaskan baik menggunakan angka-angka maupun kata-kata (Punaji, 2010).

Metode penelitian yang digunakan adalah observasi untuk melihat langsung sistem pemeliharaan dokumen rekam medis yang dilakukan di rumah sakit dan melakukan wawancara kepada petugas rekam medis di rumah sakit untuk mendapatkan informasi terkait pelaksanaanpemeliharaan dokumen rekam medis di rumah sakit. Waktu penelitian yang dilakukan di Rumah Sakit Dr. Pirngadi Medan dimulai pada bulan Maret-April 2019. Tempat yang dilakukan dalam penelitian ini adalah Rumah Sakit Dr. Pirngadi Jalan Prof. HM. Yamin Sh No. 47, Perintis, Medan Timur, Kota Medan, Sumatera Utara. Peneliti melakukan penelitian ini karena 
rumah sakit Dr. Pirngadi Medan belum melaksanakan pemeliharaan terhadap dokumen rekam medis di ruangan filling.

B. Sampel

Sampel adalah sebagian populasi, yang ciri-cirinya diselidiki atau diukur. Unit sampel dapat sama dengan populasi, tetapi dapat juga berbeda. Sampel yang digunakan dalam penelitian ini sebanyak 3 orang petugas rekam medis Rumah Sakit Dr. Pirngadi Medan.

C. Teknik Sampeling

Teknik sampling pada penelitian ini adalah total sampling, yaitu pengambilan sampel yang dilakukan dengan mengambil semua populasi. Jadi sampel dalam penelitian ini mengambil jumlah petugas rekam medis dengan jumlah sebanyak 3 orang.

D. Teknik Pengolahan Data

Setelah data dikumpul maka dilakukan pengelolahan data yang diolah secara:

1. Editing, yaitu melakukan pemeriksaan terhadap kelengkapan dan kejelasan jawaban kuesioner dan penyesuaian data yang diperoleh dengan kebutuhan penelitian.

2. Coding, yaitu kegiatan mengklasifikasikan data, memberi kode untuk masingmasing kelas terhadap data yang diperoleh.

3. Skoring, yaitu pertanyaan yang diberikan skor hanya pertanyaan yang berhubungan dengan pelaksanaan pemeliharaan dokumen dan ruang filling.

4. Entry, yaitu data yang sudah diberi kode kemudian dimasukkan kedalam komputer.

E. Variabel Penelitian

Variabel dalam penelitian ini adalah dokumen rekam medis, ruangan filling, dan pelaksanaan pemeliharaan dokumen rekam medis.

F. Defenisi Operasional

Tabel 1. Defenisi Operasional

\begin{tabular}{|c|c|c|}
\hline No & Variabel & Defenisi Operasional \\
\hline 1 & Dokumen rekam medis & $\begin{array}{l}\text { Berkas rekam medis yang berisikan catatan tentang } \\
\text { pengobatan, pemeriksaan dan tindakan yang } \\
\text { mengalami patah atau cedera yang diakibatkan oleh } \\
\text { kecelakaan, sakit dan sebagainya. }\end{array}$ \\
\hline 2 & Ruangan filling & $\begin{array}{l}\text { Tempat untuk menyimpan berkas rekam medis } \\
\text { pasien rawat jalan, rawat inap, dengan } \\
\text { mempertimbangkan suhu, kelembaban, APAR dan } \\
\text { pemeliharaan dokumen. }\end{array}$ \\
\hline 3 & $\begin{array}{l}\text { Sumber Daya Manusia } \\
\text { (SDM) }\end{array}$ & $\begin{array}{l}\text { Orang yang melakukan pemeliharaan dokumen } \\
\text { rekam medis. }\end{array}$ \\
\hline
\end{tabular}

\section{HASIL DAN PEMBAHASAN}

\subsection{Hasil}

Berdasarkan hasil observasi yang penulis lakukan di Rumah Sakit Dr.Pirngadi Medan, diketahui bahwa ruang penyimpanan terletak di lantai 2, masih terdapat dokumen rekam medis yang rusak dan belum diganti dengan yang baru, banyak dokumen rekam medis yang diletakkan di lantai dalam keadaan tidak bersampul. Untuk rak penyimpanan masih menggunakan lemari kayu dan belum menggunakan lemari roll o'pack.

Berdasarkan wawancara yang dilakukan penulis terhadap informan mengenai Tinjauan Pelaksanaan Pemeliharaan Dokumen Rekam Medis Di Ruang Filling Rumah Sakit Dr. Pirngadi Medan Tahun 2019, diperoleh hasil yang hampir serupa antar jawaban yang satu 
dengan jawaban yang lainnya dari masing-masing informan. Hasil wawancara yang dilakukan terhadap 3 informan yaitu :

Bagaimana kondisi ruangan penyimpanan rekam medis di Rumah Sakit Dr.Pirngadi Medan?

"Ruang penyimpanan nya itu cukup luas tetapi masih belum memadai, dan juga masih banyaknya fasilitas yang kurang seperti rak".

Informan 1, 2, 3

Apakah petugas penyimpanan mempunyai tugas dan tanggungjawab masingmasing?

"Sudah ada tugas dan tanggungjawab masing-masing petugas, seperti melayani permintaan dari ruangan, poliklinik, penelitian, mengemap dan meretensi".

Informan 1, 2, 3

Apa saja yang menyebabkan dokumen rekam medis rusak?

"Sebenarnya yang menyebabkan dokumen rekam medis itu rusak banyak. Misalnya, lemari nya masih menggunakan kayu dan belum menggunakan lemari rool o'pack, otomatis kan dokumen rekam medis cepat berdebu, cepat diserang rayap, dan cepat rusak atau sobek. Penyebab lainnya juga bisa dilihat dari dokumen rekam medis yang tidak memiliki sampul, karena kurangnya sampul untuk dokumen rekam medis dan sampul belum sesuai dengan standar karena masih menggunakan sampul berbahan kertas yang mudah basah. Kemudian banyak nya hekter serta sering digigit oleh tikus".

Informan 1, 2, 3

Apa yang harus dilakukan jika dokumen rekam medis rusak?

"Yang dilakukan jika dokumen rekam medis rusak yaitu langsung mengganti sampul dokumen tersebut dengan yang baru, dan yang belum ada sampulnya harus di kasi sampul agar terlihat rapi".

Informan 1, 2, 3

\section{Apakah di dalam ruangan penyimpanan ada alat pemadam kebakaran (APAR)?}

"Iya ada, alat pemadam kebakaran di ruangan penyimpanan berjumlah 3. Karena kan ini ruangan nya banyak berkas dan bisa di bilang ruangan yang gampang terbakar, jadi ya harus ada alat pemadam kebakarannya dan letaknya ada yang di depan, tengah sama belakang”.

Informan 1, 2, 3

Apakah di ruang penyimpanan ada larangan masuk selain petugas penyimpanan?

"Ada, namun masih ada juga petugas yang bolak balik masuk karena kepentingan lain, dan apabila ada kepentingan maka petugas lain akan di suruh tunggu di luar, dan apabila ada petugas yang sudah izin, maka di perbolehkan untuk masuk".

Informan 1, 2, 3

Apakah alat pendingin ruangan dimatikan atau dihidupkan ketika petugas pulang?

"Jika petugas pulang, maka otomatis semua pendingin ruangan, kipas angin dan lampu juga dimatikan. Jika dihidupkan listrik tidak narek".

Informan 1, 2, 3 


\subsection{Pembahasan}

Berdasarkan hasil penelitian tentang pelaksanaan pemeliharaan dokumen rekam medis di Rumah Sakit Dr.Pirngadi Medan menunjukkan bahwa untuk aturan dan prosedur di penyimpanan sebagian besar sudah sesuai dengan teori, akan tetapi masih ada yang belum sesuai dengan teori, yaitu terdapat rak yang masih menggunakan kayu dan belum menggunakan lemari rool o'pack, serta masih ada dokumen rekam medis yang terletak di bawah lantai, terdapat folder rekam medis yang rusak dan belum diganti dengan yang baru karena kurangnya persediaan sampul. Suhu dan kelembapan ruangan yang terdapat di dalam ruangan penyimpanan juga kurang terkontrol, sedangkan untuk kelembapan suatu ruangan penyimpanan berdasarkan teori sekitar $40 \%$ sampai $60 \%$ dan suhu udara berkisar antara $18^{\circ} \mathrm{C}$ sampai $24^{\circ} \mathrm{C}$, apabila suhu kurang dari normal, maka dalam waktu relative singkat arsip-arsip akan rusak. Di ruangan penyimpanan juga belum adanya alat pengukur suhu dan kelembapan, padahal alat tersebut sangat membantu dalam pemeliharaan dokumen rekam medis. Petugas rekam medis yang ada di ruangan penyimpanan sudah memiliki tugas dan tanggungjawab masing-masing.

\section{KESIMPULAN}

Berdasarkan hasil dari penelitian yang berjudul "Tinjauan Pelaksanaan Pemeliharaan Dokumen Rekam Medis Di Ruang Filling Rumah Sakit Dr. Pirngadi Medan Tahun 2019” yang telah dijabarkan diatas dapat disimpulkan bahwa pelaksanaan pemeliharaan dokumen rekam medis masih belum memadai karena rak penyimpanan yang masih menggunakan kayu sehingga menyebabkan mudahnya terserang rayap, rak yang masih kurang sehingga menyebabkan dokumen rekam medis ada yang diletakkan di bawah lantai. Dari aspek fisik belum memadai, karena masih adanya folder atau dokumen rekam medis yang belum diberi sampul dan belum mengganti folder yang rusak dengan yang baru. Suhu dan kelembapan ruangan yang kurang dan belum memenuhi standar teori yang ada.

\section{REFERENCES}

Budi, S. C. (2011). Manajemen Unit Kerja Rekam Medis. Yogyakarta: Quantum Sinergis Media.

Hatta, G. (2012). Pedoman Manajemen Informasi Kesehatan di Sarana Pelayanan Kesehatan. Jakarta: UI-Press.

Hutauruk, P. M., \& Astuti, W. T. (2018). Tinjauan Aspek Keamanan dan Kerahasiaan Dokumen Rekam Medis Di Ruang Filling Rumah Sakit Khusus ( RSK ) Paru Medan Tahun 2018. Jurnal Ilmiah Perekam Dan Informasi Kesehatan Imelda, 3(2), 510-518.

Menkes RI. (2013). Peraturan Menteri Kesehatan Nomor 55 Tahun 2013 tentang Penyelenggaraan Pekerjaan Perekam Medis. Jakarta: Menkes RI.

Ni, Pramesti. (2014). Pemeliharaan rekam Medis Inaktif Pasien di rSJ Grhasia DIY. http://etd.respository.ugm.ac.id./index.php?mod=penelitian_detail\&syb=PenelitianDet ail\&act=view\&typ=html\&buku_id=71997. Di akses pada tanggal 10 April 2019.

Notoadmodjo, S. (2012). Metodologi Penelitian Kesehatan. Jakarta: Rineka Cipta.

Peraturan Menteri Kesehatan Republik Indonesia No.269/Menkes/Per/II/2008/. Tentang Rekam Medis. Jakarta: Kemenkes RI. 
Rustiyanto, (2014). Etika Profesi Perekam Medis dan Informasi Kesehatan. Yogyakarta: Politeknik Kesehatan Permata Indonesia.

Rustiyanto, E., \& Rahayu, W. A. (2011). Manajemen Filing Dokumen Rekam Medis dan Informasi Kesehatan. Politeknik Kesehatan Permata Indonesia.

Sandika, T. W., \& Ernianita. (2019). Tinjauan Pelaksanaan Pemeliharaan Dokumen Rekam Medis di Ruang Filing Rumah Sakit Jiwa Prof.Dr.Muhammad Ildrem Medan Tahun 2018. Jurnal Ilmiah Perekam Dan Informasi Kesehatan Imelda, 4(1), 560-566. http://jurnal.uimedan.ac.id/index.php/JIPIKI/article/view/77.

Sugiyono. (2010). Metode Penelitian Pendidikan Pendekatan Kuantitatif, Kualitatif dan $R \& D$. Bandung: Afabeta.

Sugiyono. (2011). Metode Penelitian Kuantitatif, Kualitatif dan R\&D. Bandung: Afabeta.

Sugiyono. (2015). Metode Penelitian Pendidikan (Pendekatan Kuantitatif, Kualitatif dan $R \& D)$. Bandung: Afabeta.

\section{BIOGRAPHIES OF AUTHORS}

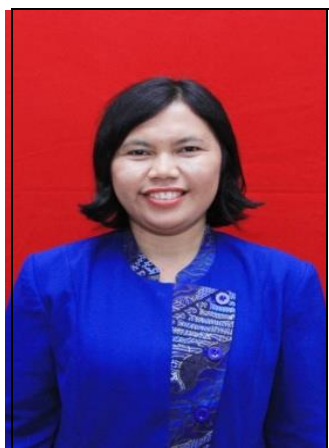

Esraida Simanjuntak, Gelar D-III diperoleh dari Akademi Keperawatan Pemkab Tapanuli Utara, Jurusan Keperawatan pada tahun 2006, Gelar Sarjana diperoleh dari Universitas Sumatera Utara, Fakultas Kesehatan Masyarakat tahun 2009, Magister Kesehatan diperoleh dari Universitas Sumatera Utara, jurusan Ilmu Kesehatan Masyarakat pada tahun 2017. Saat ini aktif sebagai dosen tetap di Prodi D-III Perekam dan Informasi Kesehatan Universitas Imelda Medan dan menjabat sebagai sekretaris Prodi. 